\title{
МОТИВАЦІЙНА МАРКОВАНІСТЬ ВІДІМЕННИХ ДІЕСЛІВ У НАЦІОНАЛЬНО-МОВНОМУ ЛАНДШАФТІ ПИСЕМНИХ ПАМ'ЯТОК СТАРОУКРАЇНСЬКОЇ МОВИ ХIV-XVII СТ.
}

\author{
Кочерга Г. В., Мартиновська Ю. О.
}

\section{ВСТУП}

Українська система афіксального словотвору дієслів у мові писемних пам'яток староукраїнського періоду XIV-XVII ст. створена на основі вже наявних у мові ресурсів попередніх періодів. Словотвірний акт, у якому вихідною одиницею виступає іменна частина мови, а похідною - дієслово, є унікальним мовним явищем, оскільки для нього характерна кардинальна семантична трансформація: значення субстантивності трансформується у значення процесуальності. Дослідження словотвірних структур та мотиваційних процесів відіменникових дієслів староукраїнської літературної мови у проєкції на психоментальні структури свідомості $€$ перспективним, що й окреслює актуальність дослідження.

Українська дериватологія успадкувала значущий теоретичний і практичний доробок у плані дослідження словотвірної системи мови, типів та способів словотвору (праці I. Ковалика, I. Вихованця. Л. Гумецької, Т. Возного, С. Бевзенка, В. Німчука, В. Горпинича, Л. Юрчук, І. Яценка, Н. Клименко, Л. Дідківської, К. Городенської, В. Грещука, О. Безпояско, Л. Родніної, В. Русанівського та ін.). Відіменні деривати у словотворчому аспекті глибоко досліджені К. Городенською та М. Кравченко. Теоретичні засади когнітивноономасіологічного аналізу мовних одиниць закладено О. Кубряковою, українськими дослідниками С. Жаботинською, О. Селівановою. Українські відіменникові дієслова у сучасній українській літературній мові досліджено Г. Кочергою.

Дериваційна система українського дієслова ще не $є$ всебічно дослідженою в аспекті діахронії. Суфіксальний історичний словотвір дієслів описаний не досить, здебільшого принагідно ${ }^{1}$, у контексті розв'язання інших мовознавчих проблем. Словотвірні дослідження здійснювано переважно на обмеженій джерельній базі. Тому особливої

Штанденко У.М. Відіменний суфіксальний словотвір дієслів у староукраїнській мові XIV-XVIII ст. Київ : Інститут української мови НАН України, 2008. 208 c. 
уваги набули питання творення дієслів на різних етапах розвитку української літературної мови ${ }^{2}$, зокрема, в якому напрямі та яким чином відбувався розвиток дієслівної системи, які мотиваційні особливості щодо пояснення зв'язку ономасіологічної структури слова зі структурами знань про об'єкт номінації, що відображають особливості національної мовної картини світу українського етносу ${ }^{3}$.

Мета роботи - описати та дослідити закономірності вираження відіменникових дієслівних утворень у староукраїнській літературній мові: мотиваційної моделі, структури, семантики та функціонування.

Мета роботи передбачає розв'язання таких завдань: охарактеризувати мотивацію староукраїнських відіменникових дієслів; дослідити асоціативно-термінальну мотивацію відіменникових дієслівних одиниць у писемних пам'ятках староукраїнської літературної мови; описати різновиди пропозиційно-диктумної мотивації відіменникових дієслів; здійснити аналіз інтерпретації ономасіологічної ознаки та проблем структур репрезентації знань.

Методи дослідження. Відповідно до мети роботи та характеру зібраного фактичного матеріалу було вибрано такі методи дослідження: порівняльно-історичний, зіставний, описовий та методики компонентного, морфемного, словотворчого аналізів.

\section{1. Історія дісслова у формуванні системи категорійності й мотиваційності}

Жодна частина мови не зазнала стількох змін і перетворень, як слов'янське дієслово, і більшість їх припадає на доісторичний період слов'янських мов. За таких умов тільки всебічний аналіз усіх аспектів розвитку праслов'янського дієслова дасть більш-менш задовільну відповідь на наявні питання, яка, проте, навряд чи буде коли вичерпною й конструктивною ${ }^{4}$.

В. Виноградов, О. Пєшковський, Ф. Буслаєв, В. Гумбольдт, Ф. Фортунатов, К. Аксаков, О. Потебня та ін. розглядали проблему історичного дієслівного словотвору, функціональності граматичних форм, граматичних категорій, граматичної структури мови, проблему взаємовідношення мови і мислення в контексті загальнофілософської

${ }^{2}$ Бойчук В.М. Типологія внутрішньої форми слова у десубстантивному словотворі : автореф. дис. ... канд. філол. наук : 10.02.01. Івано-Франківськ, 1997. 18 с.

${ }^{3}$ Кочерга Г.В. Мотивація відіменникових дієслів у сучасній українській мові (когнітивно-ономасіологічний аспект) : дис. ... канд. філол. наук. Одеса, 2003. 200 с.

4 Півторак Г.П. Історико-лінгвістична славістика. Вибрані праці. Київ : НВП «Вид-во «Наукова думка» НАН України», 2015. 512 с. 
концепції мовної картини світу ${ }^{5}$. О. Потебня у свою теорію розуміння природи слова вкладає положення теорії В. Гумбольдта про внутрішню форму. Згідно з цією концепцією слово має два значення. Одне об'єктивне, що наближене до етимологічного значення і має одну ономасіологічну ознаку. Друге значення суб'єктивне, що об'єднує в собі безліч ознак: «Перше $є$ знаком, символом, що замінює для нас друге» ${ }^{6}$. Об'єктивним змістом слова $є$ та форма, в якій нашій свідомості представлено зміст думки: «...якщо виключити друге, суб'єктивне... єдиний зміст, то у слові залишиться тільки звук, тобто зовнішня форма, i етимологічне значення, яке також $є$ формою, тільки внутрішньою. Внутрішня форма слова $є$ відношенням змісту думки до свідомості: вона показує як уявляється людині ії особиста думка» ${ }^{7}$.

Мотивацію і напрям похідності у словотворенні можна 3'ясувати, вивчивши концепцію О. Потебні, у якій дослідник намагався наблизитись до еволюції елементів людської думки у дослідженні історії частин мови ${ }^{8}$. «Слово на початку розвитку думки, - писав він, ще не має для думки значення якості і може бути тільки вказівкою на чуттєвий образ, у якому не має ні дії, ні якості, ні предмета, взятих окремо, але все це у неподільній єдності... Утворення дієслова, імені та інших частин мови - вже такий розклад і видозміна чуттєвого образу, які передбачають інші, простіші явища, які йдуть за створенням слова» ${ }^{9}$. На думку дослідника, диференціація чуттєвих образів почалася з утворення таких слів, де функції майбутніх головних частин мови імені та дієслова, ще не розчленовані. Це так звані первісні дієприкметники. Первісний дієприкметник втілював у собі два протилежні начала - імені і дієслова, 3 яких ім'я було сильнішим і виразнішим, а дієслово слабкішим, позбавленим таких істотних дієслівних ознак, як час і стан. Первісний дієприкметник нагадував більше іменник тим, що, як і сучасний дієприкметник, зображав ознаку, наслідок діяльності предмета, але так, що вона виключала думку про цю діяльність, - ознака поставала нібито готовою, даною. Приблизно те саме Потебня вбачав і в сучасному іменнику, але в останньому немає навіть гадки про діяльність, яка породила ознаку. I все-таки дієприкметнику не належить першість у творенні граматичних форм у людській мові - вона належить вигукові. У дієприкметнику, який

5 Виноградов В.В. Понятие внутренних законов развития языка. Bonpocbl языкознания. № 2. 1952. С. 33.

${ }^{6}$ Потебня А.А. Из записок по русской грамматике. Т. II. Харьков, 1888. С. 25.

${ }^{7}$ Потебня А. Мысль и язык. А. Потебня. Изд., 5, 1926. 214 с.

${ }^{8}$ Селіванова О.О. Складне слово: мовні моделі світу. Черкаси : ЦНТІ, 1996. 297 с.

9 Бабушкин А.П. Типы концептов в лексико-фразеологической семантике языка. Воронеж : Изд-во Воронеж. ун-та, 1996. 104 с. 
3'явився слідом за вигуком, у своїй найдавнішій формі, простежується напрям похідності сучасних частин мови ${ }^{10}$, указаний розвитком структури первісного прикметника. Він у своєму розвитку найбільш був схожий на ім'я, ніж на дієслово, і насамперед виокремились 3 первісного дієприкметника граматичні категорії імені, тобто субстанції, і це був час, коли людській думці світ уявлявся сукупністю виготовлених за людським образом і подобою, одухотворених речей, внутрішньо статичних, але одночасно зв'язаних з реальним світом та таких, що впливають на нього. Людина в усьому звикла бачити субстантивність, але в процесі історичного розвитку, в міру поступового занепаду субстанціональності, мотивація змінюється і у мисленні з'являється нове спостереження, що́ лежить в основі явищ об'єктивної дійсності, таким чином, виникає нова категорія думки дієслівність. Вона утворилась 3 первісного дієприкметника не пізніше іменника (гіпотетично), що послугувало утворенню інфінітива (спочатку був іменником, а потім набув ознак дієслова) ${ }^{11}$. Складні процеси абстрагування i ускладнення людської думки дають можливість розвитку глибшої граматикалізації дієслова, що спонукало дієслово, крім стадії інфінітива, виробити таку форму, яка б прив'язала дію до особи, до моменту мовлення, до їі виконавця і об'єкта, іншими словами - зв'язувала їі з дійсністю ${ }^{12}$. Такою формою був індикатив, або дійсний спосіб, який мав здатність виражати відтінки дії за допомогою своїх категорій особи, стану, часу, що було простежено О. Потебнею на матеріалі східнослов'янських і споріднених з ними мов ${ }^{13}$.

Спираючись на погляди В. Гумбольдта і Г. Штейнталя, дослідник створив своєрідну філософсько-лінгвістичну теорію дієслівності, яка стала важливою основою його вчення про історичний розвиток головних категорій мови $\mathrm{i}$ мислення. У лінгвістичній концепції О. Потебні дієслово виступає як найвища, найбільш абстрактна і гнучка, конструктивна і постійно прогресуюча категорія людської мови. Процес виникнення і формування дієслова, що відображав

10 Кияк Т.Р. Мотивированность лексических единиц. Львів : Вища школа, 1988. $161 \mathrm{c}$.

11 Лукин М.Ф. Переход слов из одной части речи в другую и их трансформационные причинно-следственные связи в современном русском литературном языке. Проблемы словообразования русского и украинского языков. Киев-Донецк : Вища школа, 1976. С. 5-33.

12 Погиба Л.Г. Семантичне поле відіменникових дієслів спільної дії в сучасній українській мові. Питання граматичної будови украӥнськоӥ мови : збірн. наук. праць. Київ : Вид-во КДПІ, 1979. С. 75-87.

13 Бевзенко С.П. Із історії словотвору дієслів української мови. Наук. збірн. Ужгородського ун-ту, 1958. Вип. 35. С. 3-20. 
важливий етап в інтелектуальному розвитку людини, відбувся одночасно 3 переходом від давньої іменної структури речення до дієслівної $^{14}$. Набираючи сили та міцно вкорінюючись у семантичну і синтаксичну системи мови, дієслово поступово i невідворотно розвиває категорію абстрактності. Означаючи дію, процес, дієслово виокремлюється із синкретизму первісного слова вже після іменника i прикметника $i$, пройшовши через стадію дієприкметника й інфінітива, як проміжних ланок між іменем і дієсловом, виробляє в собі категорії особи, виду, часу, способу, стану ${ }^{15}$. Дієслово починає витісняти імена зі своїх основних граматичних позицій, підкоряючи собі інші категорії, сприяючи зростанню дієслівних типів речення за рахунок номінативних, іменних. Дія, процес, втілені у дієслові, поступово руйнують сферу субстанціональності імені. Граматичний вплив дієслова поширюється на ті групи слів, які колись були зв'язані з іменником - антитезою дієслова, підкреслює О. Білодід, що було сприйняте Д. Овсянико-Куликовським та О. Пєшковським.

Отже, староукраїнська дієслівна деривація в діахронії апелює до праслов'янської спадщини. Це свідчить про істотні трансформації граматичної будови української мови в період формування й існування праслов'янської мови. Дієслівне суфіксальне словотворення може виступати індикатором таких змін як у формальному, так і у семантикокогнітивному аспектах. Процес становлення українського словотвору не може бути відтворений без використання відомостей порівняльноісторичного вивчення словотворчих процесів сучасної української літературної мови, староукраїнської та давньокиївської мов.

Одним 3 найефективніших способів поповнення лексичного мовного фонду досліджуваного періоду XIV-XVII ст. $є$ суфіксальне словотворення, що визначається як система чи підсистема загальної мовної системи і складається із сукупності словотвірних класів, словотвірних типів, словотвірних моделей.

\section{2. Механізм мотивації відіменних дісслівних дериватів}

із суфіксами -и-, -a-(А), -b- (> -i-) у староукраӥнській мові

Дієслівна система української мови успадкована 3 праслов'янської доби і з найменшими змінами відбита у системі старослов'янського дієслова. В історії розвитку, становлення окремих слов'янських мов зазнала змін і щодо цілості й чистоти успадкованих типів, і щодо

14 Ширшов И.А. Множественная словообразовательная мотивация в современном русском языке. Ростов-на-Дону : Изд-во Кубанского ун-та, 1981. 117 с.

15 Янценецкая М.Н. Семантические вопросы теории словообразования. Томск : Изд-во Алтайского ун-та, 1979. 237 с. 
продуктивності окремих дієслівних формантів. Трансформація різних дієслівних основ, з одного боку, утворила нові типи дієслів, з іншого боку, дала підставу для виникнення паралельних синонімічних типів дієслова ${ }^{16}$.

Дісслова із суфіксом -и-. Під час утворення дієслівних одиниць в усіх слов'янських мовах використовується давній суфікс *-i-, який бере свої початки у праслов'янській мові. Його континуанти функціонують у сучасних слов'янських мовах, *-iti < укр. -и- (ти): ГНОИТИ, БһСИТИ, МЕРЗИТИ, ДЬЯЧИТИ, ПЛОТИТИ, ВИХРИТИ, БОЛОТИТИ, ХЛЮБИТИСЯ, ЦАРИТИ. На думку Ф. Славського ${ }^{17}$, у праслов'янській мові за допомогою суфікса *-і- утворювались дієслова від основ іменників, прикметників, прислівників: ХЛЮБА (пЛ. *chluba). Надменность, высокомерие, чванство. $\rightarrow$ ХЛЮБИТИСЯ, ШКАРОДА (пл. *szkaradzic). Гнусность, мерзость. $\rightarrow$ ШКАРАДИТИ, БЛЮЗНһРЦА (пл. bl*uźnierca). Поноситель, хулитель, богохульник. $\rightarrow$ БЛЮЗНИТИ тощо. Дослідник А. Мейе зазначав, що у слов'янських мовах «для утворення дієслівних одиниць на *-iti- 3 каузативним значенням могли правити будь-які імена» ${ }^{18}:$ БУБЕНЬ $\rightarrow$ БУБНИТИ (Бить (в барабан), ЛИХВА $\rightarrow$ ЛИХВИТИ, дієсл. Лихоимствовать, брать лихву, ВОЕВОДИТЕЛЬ (воевода) - ВОЕВОДИТИ (Предводительствовать, руководить войском) тощо.

Мотивована диктумом відіменникова дієслівна одиниця є знаком центрального компонента ситуації, а його мотиватор - певним іiі аргументом, що дає можливість виокремити різновиди пропозиційнодиктумної мотивації на підставі вибору мотиватора ${ }^{19} 3$ таких аргументів диктуму:

суб'єкта, представленого релятивом - суб'єктом певного соціального відношення: ДьяЧИТИ. Отправлять обязанности дьячка. Тотъ попъ не поетъ нынһ у тое церкви, у которой тотъ диякъ диячитъ. АИ I, 144. XVI в. 1494 г. [Матеріали до словника писемн. та книж. укр. мови XV-XVIII ст., кн. 1, ст. 63]; АРХИМАНДРИТИТИ (АНХИМАНДРһТИТИ). Исполнять должность архимандрита (1572): Владыка Леонидъ учалъ говорити [архимандриту Юрьева монастыря] Феоктисту: почему деи и ты.. мнh своей настольной грамотһ не кажешь и не (по)дписываешь? как ди ты анхимандрһтишь? Новг. II лет. 113.

16 Гумецька Л.Л. Нарис словотворчої системи української актової мови XIV-XV ст. Вид-во Академії Наук Української РСР. Київ, 1958. 297 с.

17 Штанденко У.М. Відіменний суфіксальний словотвір дієслів у староукраїнській мові XIV-XVIII ст. Київ : Інститут української мови НАН України, 2008. 208 c.

${ }^{18}$ Там само.

19 Селіванова О.О. Складне слово: мовні моделі світу. Черкаси : ЦНТІ, 1996. 297 c. 
ВАТАМАНИТИ. Быть ватаманом, исполнять обязанности ватамана. Взяли у Микитки у Лодыги на сына гривну Варсоноф<ь $>$ ева долгу в Неноксе ватаманилъ. Ки. прих. Корел. м. № 939, 5 об. 1571 г.; ВОЕВОДИТЕЛЬ, м. То же, что воевода - ВОЕВОДИТИ. Предводительствовать, руководить войском. И сия отмьщати повелһваемъ не тъчию гражаньскыимъ, нъ и воеводящиимъ къняземь. Ефр. Корм., 788. ХІІ в.; ВОЦАРИТИ. Возвести на престол. Въ царствующемъ же градһ Москвһ вси, или убо страха ради и шатания народскаго, яко мнози хотяху воцарити лжеименнаго Димитрия. ДАИ II, 197. 1619 г. [Матеріали до словника писемн. та книж. укр. мови XV-XVIII ст., кн. 1, с. 71]; ВОЦАРИТИСЯ. Вступить на престол, стать царем. И вскорһ треклятый воцарися того же 113 году, июля въ 1 день недһльный, и пача многия пакости въ царствующемъ градһ творити. Ин. Сказ., 55. XVII в. [Матеріали до словника писемн. та книж. укр. мови XV-XVIII ст., кн. 1, с. 71]; ВОЦһСАРИТИСЯ. То же, что воцаритися. Поите, яко царь всеи земли бьгъ, поите разумно. Въцсарися бьгъ надъ языкы (Сл. мт. Илариона) Мус.-Пушк. сб., 57. 1414 г. ХІ в.; ГОСУДАРИТИСЯ. Брать на себя власть государя; управлять государством. И мною владһсте, и всю власть сь меня снясте, и сами государилися, какъ хотһли, а съ меня есте государство сняли: словомъ язъ былъ государь, а дһлом ничево не владһлъ. (Ив. Гр. Посл. II, 120. XVII в. 1577 г.). У процесі творення староукраїнських відіменникових дієслів, представлених релятивом - суб'єктом певного соціального відношення, $\epsilon$ пряма мотивація з аргументами диктуму, що встановлюють когнітивні зв'язки з предикатом дієслівної одиниці, і використовується одна 3 найбільш істотних ознак предмета, що $є$ об'єктом найменування.

У староукраїнських відіменникових дієсловах із суфіксом -и- під час словотвору відбуваються мотиваційні процеси, зумовлені дифузною природою інтеграції за аналогією двох концептуальних сфер за відсутності алгоритму переносу, мотиватор дієслова пов'язаний не 3 одним компонентом диктуму, а 3 цілим комплексом асоціацій. До такого різновиду мотивації відносимо дифузно-метафоричний: ВОЗДИЧИТИСЯ. Уподобиться дикому животному, рассвирепеть. Своего цесара не пощадһша и своего $>$ сродника... тако ся въздичиша. Флавий. Полоню Иерус., II, 4. XVI в. $\infty$ XI в. [Матеріали до словника писемн. та книж. укр. мови XV-XVIII ст., кн. 1, ст. 41]; ЗВЪРИТИСЯ. Свирепеть, злиться. Толико есть смиреномудрие добро! толико есть прибытокь не хапатися еже отъ инъхъ укоризнами, ниже звъритися противу искрђняго досадамь. ВМЧ, Сент. 14-24, 835. XVI в. [Матеріали до словника писемн. та книж. укр. мови XV - XVIII ст., кн. 1, ст. 65]; ЗАЮШИТИСЯ, гл. Остервениться, сделаться кровожадным. Яко 
волци пастырообразные на стервһ церковного лихоимства крһпко сһдять и заюшилися суть. АЮЗР. II, 240 (И. Выш); БһСОВАТИСЯ, дієсл. недок. 1. Те саме, що беситися у 1 знач.: Таков бо есть ее закон своевольный: с под ярма тһснаго.. жития и пути, ведущаго во живот вһчный, выламавшися и вискочивши, буяти, шалһти и бһсоватися (1608-1609 Виш. Зач. 202); 2. (на що) Скаженіти, лютувати: Длф чого(ж) теды бһсuю(т)са на бльгочестїе, если нһ мае(т) миси а ты мuсо(м) его ведешъ, который есть вышше всфкого примише(н), (Вільна, 1596 3. Каз. 90 зв.) [СУМ XVI-XVII ст., випуск 3, ст. 151]; БһСНОВАТИСЯ, БһСНОВАТИСа дієсл. недок. Те саме, що беситися в 1 знач.: гьди змили(и)са.. на(д) сьно(м) мои(м) поне(ж) на по(в) м(с)ць бһсниетса (XVI ст. УЄ № 29519, 94 зв.) [СУМ XVI-XVII ст, випуск 3, с. 32]; ЗАЯДОВИТИСЯ дієсл. Розюшыцца, розлютовацца, прийти у шаленство. тые жолнере мһстцы поведали шп\#т своимъ, иж зъ шчю того жолънера, хтоколвекъ былъ, бо не вһдали жебы то Атыл\# был, искры >къ бы шгнистые блискали с\#, кгды на них за>довитившы с\# гледел (Атыла, 222) [Матеріали до словника писемн. та книж. укр. мови XV-XVIII ст., кн. 1, ст. 101]; ВЗБһСИТИ. 1. Привести в бешенство, исступление, взбесить, поразить безумием, бешенством. Ты [кур] лихой человек, закричал на сонных людей, будта тебя взбесила или варагуша подымала. Сказ. о куре и лисице, 194. XVIII в. $\infty$ XVII в. [Матеріали до словника писемн. та книж. укр. мови XV-XVIII ст., кн. 1, с. 78]; ЗАПЪНИТИСЯ, ЗАПЪНИВСЯ. С пеной у рта от бешенства. В тож время услышаше лоскотъ и сапание по льсу, понеже кабанъ устрашенъ и раздраженъ видя ихъ толь мало, бежа на нихъ запънився. Мелюзина, 88. XVII в. [Матеріали до словника писемн. та книж. укр. мови XVXVIII ст., кн. 1, с. 61]. Отже, дифузна природа трансформації двох концептів відіменникових дієслів у староукраїнській мові відбувається за допомогою низки асоціацій, мотивованими на підставі аналогій 3 навколишнім світом, i фіксуються як неістинні метафоричні позначення.

У староукраїнській літературній мові відіменникові дієслова марковані експерієнтивом як носієм психічної діяльності: БЛАЗЕНЪ ч. (стп. blazen) 1. (особа при дворі короля або князя, що розважала гостей різними жартами, витівками) жартівник, блазень. 2. Дурень, юродивий, блазень. БЛАЗНЬ ж (цсл. блазнь) спокуса, помилка, обман. БЛАЗНИТЕЛЬ ч. (цсл. блазнитєль) спокусник, ошуканець, шахрай. БЛАЗНИТИ, дієсл. недок. (цсл. блазнити) (кого і без додатка) спокушати, ошукувати, обманювати: не блазнһте себе маючимъ ядһние(м) (1489 чет. 304 зв.) [СУМ XVI-XVII ст., випуск 2, с. 111]; БЛАЗНИТИСЯ дієсл. недок. (цсл. блазнитиса) 1. (чим) Обманюватися, спокушатися, помилятися: не блазнитесव мыслью 
вашею (1489 чет 43 зв.). 2. (о кім) (відзиватися про когось негарно, шкодити добрій славі кого-небудь) компрометувати (кого): Ликавые дишһ нечистого сумнһнф и $\mathrm{w}$ христһ блазнфтса, не тольно w добром человһцh (поч. XVII ст. Вол. В. 97); 3. (за що) обурюватися (чим): И такъ ся блазнили жидове тоты и ище за едно слово (XVI ст. НС 44 зв.) [СУМ XVI-XVII ст., випуск 2, с. 111]; БЛЮЗНһРЦА, с.м. (пл. bluźnierca). Поноситель, хулитель; богохульник. БЛЮЗНИТИ, дієсл. (пл. bluźnić). Поносить, клеветать; богохульствовать. Бер. 188. Мл. Сл. 7. Сирійчики блюзнили Бога Ізраилского. Рук. хр. 115 [Матеріали до словника писемн. на книж. укр. мови XV-XVIII ст., кн. 1, с. 59]; БЛЮЗНИТИСЯ, дієсл. Хулиться. И многіи пойдуть вслһдъ ихъ нечистотъ, презъ которыхъ дорога истинная блюзнити ся будетъ. Пал. 315 [Матеріали до словника писемн. на книж. укр. мови XV-XVIII ст., кн. 1, с. 59]. Староукраїнські відіменникові дієслова, виражені суб'єктом, що є носієм психічної діяльності, як і в сучасній українській літературній мові, мають високий ступінь експресивності, що позначають особливості людської поведінки. Зазвичай мають переважно негативну оцінку.

Продуктивність мотиватора медіатива як допоміжного матеріалу або непрямого засобу дії староукраїнських відіменникових дієслів $\epsilon$ широким: ОГНОИТИ, дієсл. Покрыть навозом; осквернить. Огноити дворъ. АЮЗР. І, 79 (1531). Образъ Божій огноили есте. АЮЗР. II, 226 (И. Выш.) [Матеріали до словника писемн. та книж. укр. мови XVXVIII ст., кн. 1, ст. 111]; УБОЛОТИТИ, дієсл. Запачкать грязью, загрязнить. Я (правһ) умыю нозһ того убогого уболоченые. Рад. 84 [Матеріали до словника писемн. та книж. укр. мови XV-XVIII ст., кн. 2, c. 411]; ЗАМУСОРИТИ. Замусорить. Отъ самаго Царяграда и Чернаго моря по всему БЪлому морю не сыщешь нигдђ ни единаго мъста чистаго, гдъ мы Һхали, но вездъ засорено и замусорено бълымъ камнемъ. Арс. Сух. Проскинитарий, 25. 1653 г. [Матеріали до словника писемн. та книж. укр. мови XV-XVIII ст., кн. 1, ст. 57]; ЗАПОРОШИТИ, дієсл. Засорить, занести пилью. Запорошити око. АЮЗР, II, 237 (И. Выш.) [Матеріали до словника писемн. та книж. укр. мови XV-XVIII ст., кн. 1, с. 283]; ЗАПОТИТИ, дієсл. Покрить потом. Не проливши кровһ и чола добре не запотивши не взяти Варшавы. Вел. I, 251 [Матеріали до словника писемн. та книж. укр. мови XV-XVIII ст., кн. 1, с. 283]; ЗЛОТИТИ дієсл. недок. (стп. zlocic) (покривати щонебудь золотом або позолотою) золотити: Злочи deauro (Уж. 1645, 68) [СУМ XVI-XVII ст., випуск 12, с. 23]; ВЫЗВһЗДИТИСЯ, дієсл. Покрыться звездами. Ночъ около полночи вызвһздилась зъ морозомъ. Дн. Марк. III, 58 [Матеріали до словника писемн. та книж. укр. мови XV-XVIII ст., кн. 1, с.137]; ПОСМОЛИТИ, дієсл. Обсмолить. Смолою 
корабль посмолилъ. Рук. хр. 7 [Матеріали до словника писемн. та книж. укр. мови XV-XVIII ст., кн. 2, с. 183]. Прикладами засвідчено, що медіатив $є$ непрямим засобом дії репрезентанта і досліджується як окремий складник. Медіатив $\epsilon$ мотиватором староукраїнських відіменникових дієслів агентивної фізичної діяльності додаткової дії.

Трансгресив як результат каузації перетворення значень іменників $€$ чисельним серед відіменникових дериватів: ПОКОЗА×ИТИСЯ, ПОКОЗА $\times$ hnnbnbNNNTИ, дієсл. Сделаться казаками. Инніе сами боячися пановъ своихъ и жолнһрства, же будучи мужиками покозачились, за Хмелницкимъ на Украину уступовали. Гр. 102. Жителһ тамошніе также покозачһли. Вел. IV.76 [Матеріали до словника писемн. та книж. укр. мови XV-XVIII ст., кн. 2, с. 153]; ПОТУР×ИТИСЯ, дієсл. Отуречиться. Ся Луцкій владыка потурчиль. АП. 1246. [Ивоня] для богатства потурчился, Боб. 291 [Матеріали до словника писемн. та книж. укр. мови XV-XVIII ст., кн. 2, с. 196]; ОТИРАНИТИ, дієсл. Сделать тиранским. Римскій епископъ... имя отираниль посполитое. АП. 1676 [Матеріали до словника писемн. та книж. укр. мови XV-XVIII ст., кн. 2, с. 63]; ГНОИТИ. 1. Гноить (доводить до гниения). Поставилъ тотъ Ларионъ дворъ себъ... и съ своихъ хоромъ водной потокъ попустиль на наши домовые Никольские дворишка и заплоты и хоромы у нашихъ дворовъ гноитъ. АХУ III, 64. 1628 г. 2. Удобрять. Преж тамо насьють бобу... после его заоруют... и тьмъ то добрь гноять землю. Назиратель, 302. XVI в. [Матеріали до словника писемн. та книж. укр. мови XV-XVIII ст., кн. 1, ст. 51]; ГНОИТИСЯ. Гноиться. [Матеріали до словника писемн. та книж. укр. мови XV-XVIII ст., кн. 1, ст. 51]; ОМЕДВИТИ, омедвлю. Усладить. Сладостию словесъ твоихъ миръ весь омедви, въ всю землю изыдоша

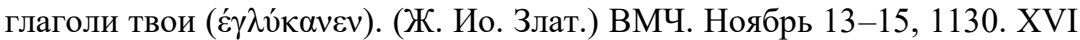
в. [Матеріали до словника писемн. та книж. укр. мови XV-XVIII ст., кн. 1, ст. 111]; ОСМОРОДИТИСЯ, гл. Провоняться. Которыми [смолою, дегтемъ] бысь моглъ и помазати и осмородити. Пал. 657 [Матеріали до словника писемн. та книж. укр. мови XV-XVIII ст., кн. 2, с. 91]. Сфера трансгресива $€$ різноманітною серед мотивованих іменників i чисельною серед староукраїнських відіменникових дієслів як результату каузації перетворення.

Староукраїнські відіменникові дієслова окреслені локативом просторовим компонентом - диференціюють дієслівні деривати на позначення трудової діяльності: ПЛОТИТИ. Создавать, связывать плоты, плотить. Кладутъ ихъ хрестьяне дрова на рекһ на своемъ берегу да плотятъ деи плоты по своимъ берегомъ. Арх. Стр. I, 131. 1507 г. Ср. плотати; ОБТЫНИТИ, дієсл. Окружить (плетнем). Въ гумне клуня тыномъ обтыненая. Кн. Луцк. 1571, л. 213 [Матеріали до словника 
писемн. та книж. укр. мови XV-XVIII ст., кн. 2, с. 21]; ОСТРОГЪ, с.м. Палисад. ОСТРОЖИТИ, дієсл. Обносить палисадом. Сторона двора от ставу... острогом острожена. Пам. III, 72(1566) [Матеріали до словника писемн. та книж. укр. мови XV-XVIII ст., кн. 2, с. 58]. Диктум таких дієслівних дериватів вказує на відповідну локалізацію стосовно людини до інших речей.

Чисельна група відіменникових дієслів у староукраїнській літературній мові використовує інструментив як мотиватор на позначення діяльності за допомогою знаряддя. Інструментив знаряддя та засобу дії: СУРМИТИ, дієсл. Играть на сурме. [Тренбачи] въ сурмы сурмятъ. Клим. 209 [Матеріали до словника писемн. та книж. укр. мови XV-XVIII ст., кн. 1, с. 379]; ПОСКОРОДИТИ, дієсл. Забороновать перед посевом. [Нивы] п. Кривицкий поралити и поскородити казалъ. Кн. Луцк. 1574, л. 281 [Матеріали до словника писемн. та книж. укр. мови XV-XVIII ст., кн. 2, с.181]; РАЛО, с.ср. Плуг. Старинное орудие для пахоти земли - РАЛИТИ, дієсл. Пахать. Онъ на тое поведилъ: правда, же твои нивы оралъ и ралю и еще буду большей ралити готовое роли. Кн. Луцк. 1574, л.282 [Матеріали до словника писемн. та книж. укр. мови XV-XVIII ст., кн. 2, с. 266]; ВЫБРИТВИТИ дієсл. недок. (що) Виголити: а ты што розимһе(ш) w coбh, выбри(т)вивъши потылицю, макге(р)ки Веръ(х) рога головного повһсивши.. тобыли пок\#нї\# не треба (п. 1596 Виш. Кн. 233 зв.) [СУМ XVI-XVII ст., випуск 5, с.112]; ЗАТРУБИТИ дієсл. док. (почати трубити, видавати звуки за допомогою труби, сурми) затрубити: трибы агглскии тогды затриб\#(т) (Вільна, 1596 3. Каз. 74) [СУМ XVI-XVII ст., випуск 11, с. 8]; БУБЕНЪ, с.м. Барабан. БУБНИТИ, дієсл. Бить (в барабан). [Довбишһ] въ бубны бубнятъ. Клим. 209 [CУМ XVI-XVII ст., випуск 2, с. 56]. Мотивовані інструментивом відіменникові деривати у своїй структурі мають високий ступінь вияву ономасіологічної ознаки. У відіменникових дієсловах, маркованих інструментивом, основна роль відводиться семантиці суб'єкта активної дії, спрямованої на об’єкт, а не на знаряддя, яким вона оперує.

У староукраїнській літературній мові у відіменниковому дієслівному словотворі простежується явище псевдомотивації. Прикметним $\epsilon$ те, що на відміну від мотивації, псевдомотивація відрізняється випадковим вибором мотиватора слова, що не забезпечується мотиваційними та семантичними зв'язками. Псевдомотивація характеризується наявністю формального, умовного мотиватора у словотворчому процесі ${ }^{20}$. Наприклад: ДОждИТИ дієсл.

20 Селиванова Е.А. Когнитивная ономасіологія : монографія. Київ : Фітосоціоцентр, 2000. 248 с. 
недок. (цсл. дъждити) 2. Переносне значення. Густо, рясно спати: А Панъ дожди(л) на Содоми и Гомори сһркою и огнемъ w(т) Пана з’ нба (Київ, бл. 1619 О обр. 141) [СУМ XVI-XVII ст., випуск 8, с. 85]; ВИХРИТИ, гл. Мутить, возбуждать раздор, смуту. А чорть абы между народомъ людскимъ вихрилъ и на злое привелъ, з своей стороны вһншовалъ народу людскому. Рук. хр. 8. Ахавъ реклъ до Іліи: ты то вихришъ въ земли Ізраилской. ib. 112 [Матеріали до словника писемн. та книж. укр. мови XV-XVIII ст.., кн. 1, с. 61]; Голчити дієсл. гомонеть, крычать, шуметь. пришолъ исUсъ $\mathrm{B}^{\mathrm{s}}$ дом $^{\mathrm{s}}$ кнгжий и Uвидевши писчъки и тижьбу голчачи (Цяп., 12, 1457 г.); ШКАРОДА, с.ж. Гнусность, мерзость - ШКАРАДИТИ, дієсл. (пл. szkaradzic). Пачкать; осквернять. Гробу Христового трупами не шкарадили. Пал. 777 [Матеріали до словника писемн. та книж. укр. мови XV-XVIII ст., кн. 2, с. 496]; БЛЮДОЛИЗЪ, м. Тот, кто любит поживиться за чужой счет. БЛЮдОЛИЗИТИ. Искать чужых обедов, объедаться за чужой счет. На Павла митрополита что глядишь? Тотъ не живаль духовно, блинами все торговалъ, да оладьями, да какъ учинился попенкомъ, такъ по боярскимъ дворамъ блюдолизить научился (Ав. Кн. бес., 336. 1675 г.). Псевдомотивація у словотворчих процесах, у семантичній та морфемній структурі слова пояснюється етимологічними, діахронними процесами. Псевдомотивовані відіменникові дієслова переважно стилістично марковані і мають високий ступінь експресивності ${ }^{21}$. У словотворчій дієслівній системі староукраїнської літературної мови уже повністю сформувалися афіксальні типи, властиві й сучасній українській літературній мові, що засвідчено писемними пам'ятками. В історії становлення й розвитку української мови найменших змін зазнали загальний склад і семантика дієслівних афіксів ${ }^{22}$, але змінився склад префіксів, здатних виступати у формальній функції.

Дікслова із суфіксом - $а$-(А). Мотиваційні процеси староукраїнських відіменникових дієслів із суфіксом -а-(А) простежуються як у пропозиційно-диктумній, так і в асоціативно-термінальній мотиваціях. Дослідниця О. Кубрякова зауважує, «що звичайні зв’язки мотивуючого слова та їх відтворення у семантиці похідного $€$ важливою ознакою смислової структури дериватів» ${ }^{23}$. На думку дослідників О. Кубрякової, Л. Жаналіної, Г. Кочерги, І. Ширшова, за різновидами концептуальних

${ }^{21}$ Кочерга Г.В. Мотивація відіменникових дієслів у сучасній українській мові (когнітивно-ономасіологічний аспект) : дис. ... канд. філол. наук. Одеса, 2003. 200 с.

22 Янценецкая М.Н. Мотивационные отношения в лексике и лексическое гнездо. Семантическая структура слова. Кемерово : Изд-во Кемеровского ун-та, 1984. С. 3-17.

${ }^{23}$ Кубрякова Е.С. Теория мотивации и определение степеней мотивированности производного слова. Актуальные проблемы русского словообразования. Ташкент : Изд-во Ташкентского ун-та, 1976. С. 285-292. 
структур асоціативно-термінальна мотивація є метафоричною ${ }^{24}$, тому що вибір мотиватора дієслів відбувається зі сфери неістинних знань (асоціативно-термінальної частини концепту), що формується на підставі використання знаків однієї концептуальної сфери (донорської) на позначення іншої (реципієнтної) за аналогією. Відповідно до зв'язків асоціативно-термінальної сфери 3 іншими концептами та способів аналогізації предметних сфер виокремлюємо гештальтнометафоричний різновид: ВЫХВОСТАТИ дієсл. Выхвастать. того Григорка Василевича, іако фалшера у дыбы выхвостат и з места прочь посротку мещанъ выслати росказали (ИЮМ, XXXII, 136, 1578); ЗЛЮТОВАТИСЯ дієсл. Злітавацца, зміласцівіцца. Стравинский, неяко злютовавшисе надъ нимъ... живого пустил (АВК, $\mathrm{XX}, 134,1598)$. Гештальтно-метафоричний різновид староукраїнських відіменникових дієслів використовує мотиватор-асоціат, що виник на підставі аналогій зорових, слухових відчуттів, які формують цілісні структури свідомості гештальти.

У староукраїнських відіменникових дієсловах із суфіксом -а-(А) у словотвірному акті відбуваються мотиваційні процеси, зумовлені дифузною природою інтеграції за аналогією двох концептуальних сфер за відсутності алгоритму переносу, мотиватор дієслова пов'язаний не 3 одним компонентом диктуму, а 3 цілим комплексом асоціацій. До такого різновиду мотивації відносимо дифузно-метафоричний:

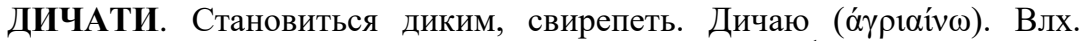
Словарь, 11, XVII в. Дичаю - свирьпствую. Алф. ${ }^{1}, 63$ об. XVII в. [Тимченко, К. 2, с. 35]; ДИВИЯТИ. 1. Дичать; звереть. Ты да азъ... свирђпъемъ и дивияемъ. М. Гр. II, 69. XVI в. [Тимченко, К. 2, с. 35]; ДИвИЯТИСЯ. Иметь дикий, необузданный нрав. Мнози же сановницы часто с нимъ бесьдующеи, словеси его повинувшеся, нравы своа дивиющаяся на кротость преложьше, удобришася жизнию. Ж. Иос. Вол. ${ }^{2}$, 21.XVI в. [Тимченко, К. 2, с. 35]; КОЖЕМЯКАТИ, гл. Называть, бранить кожемякою. АЮЗР. II, 239 (И. Выш.) [Матеріали до словника писемн. та книж. укр. мови XV-XVIII ст., кн. 1, с. 370].

Чисельною групою відіменникових дієслів у староукраїнській літературній мові є суб'єктно мотивовані експерієнтивом похідні одиниці, що виконують роль носія психічної діяльності: ЖЕБРАТИ, гл. (пл. źebrać). Выпрашивать, просить подаяние, нищенствовать. У милостей вашихъ посилку жебрати мушу. АЮЗР. II, 96 (1635) [Матеріали до словника писемн. та книж. укр. мови XV-XVIII ст., кн. 1, с. 249]; БУЯТИ, БУवТИ дієсл. недок. 1. Бушукати, бешкетувати,

${ }^{24}$ Кочерга Г.В. Мотивація відіменникових дієслів у сучасній українській мові (когнітивно-ономасіологічний аспект) : дис. ... канд. філол. наук. Одеса, 2003. 200 с. 
сваволити: Таков бо есть ее закон своевольный: с под ярма тһснаго... жития и пути, ведущаго во живот вһчный, выламавшися и вискочивши, буяти, шалһти и бһсоватися (1608-1609 Виш. Зач. 202).(проти кому) (активно діяти проти когось) [СУМ XVI-XVII ст., випуск 3, с. 104]; ВЫНУЗДАТИСЯ, ВЫНУЗДАТИСЕ дієсл. док., перен. (стати свавільним, розбещеним) розгнуздатися: пострадавши... презъ тыхъ непрыятель, которые се были вынуздали до выглаженя крови хре(с)тея(н)ско(и) шляхе(ц)ко(и) (Житомир, 1649 ДМВН 185) [СУМ XVI-XVII ст., випуск 5, с. 233]; УМАЛЯТИ, гл. Умалять, уменьшать. Квоту войска ... умаляти. Вел. I, 257 [Тимченко, К. 2, с. 427]; БЕЗДУШНИКЪ, м. Бессовестный, бесчестный человек БЕЗДУШНИЧАТИ. Поступать бессовестно. Съ папою римскимъ и съ папиною землею францужской король и француженя въ большой недружбһ, бездушничають и во всемъ лгуть, вһрить же имъ ни въ чемъ нельзя. Рим. ими. д. III, 1045. 1658 г.; ВЗБОРОНАТИ, УЗБОРОНАТИ дієсл. недок. (кому i без додатка) Забороняти: іюаннь (ж) оуз'боронАючи ємоу рєкль я и самь потрєбою (!) (1556-1561 ПЄ 27) [СУМ, Вип. 4, с. 13]; ВЗБРАНЯТИ дієсл. недок. (кому що) Забороняти: Плтая кгды дє(в)ка нєря(д)ныє ичи(н)ки чинитъ чи(с)то(ст) свою Фбражаючи а родича ма(л)жє(н)ства и вєна єє нє (в)збраняли (1566 ВЛС 77) [СУМ, Вип. 4, с. 13]; ВЗГОРШАТИ дієсл. недок. (кого) Неприємно вражати, шокувати: Прє́тожъ пи́лнє оува́жай до яки́хъ пришо́лєсь // за триднє́ній такъ в симнє́нью, яко и в' мнъма́нью $\omega$ тобъ всєє цє́ркви людс́й, кото́рых в’згорша́єшъ (Дермань, 1605 Мел. Л. 42-42 зв.) [СУМ, Вип. 4, с. 19].

Пропозиційно-диктумна мотивація

староукраїнських відіменникових дієслів із суфіксом -а-(А) $є$ неоднорідною, і в ній виокремлюємо релятив - суб'єкт певного соціального відношення: НАМһСТНИЧАТИ дієсл. недок. (1) бути намісником, виконувати обов'язки намісника: осподарь мои великии король дал ми намһстничати оу луцьску (б. м. н., 1386 Р 30) [Сл. стар. укр. м., том 2, XIV-XV ст., с. 20]; Комітатива як супровідника дії: ЛИТУРГИСАТИ, гл. Совершать литургию. Литургисати забороняетъ. Пал. 686 [Матеріали до словника писемн. та книж. укр. мови XV-XVIII ст., кн. 1, с. 405];

партоніма як частини цілого: ЗМОРЩАТИ дієсл. недок. (що) (морщити лице, робити гримасу) зморщувати: колї поститесь не бывайте ж як ліцемерници тужта (!) заморщают ліца свои, абы показалі себе людем иж посникают. (Володимир. 1571 УС Вол. 47) [СУМ XVIXVII ст., випуск 12, с. 62-63]; ПАЩЕКА. с.ж. Пасть, зев; челюсть. $\rightarrow$ ПАЩЕКОВАТИ, дієсл. Браниться, клеветать, говорить грубости, 
ложь. Птяный то я бувши, пащековавъ на цнотливого чоловһка. Ак. Полт. с. (КС. LXXV, 239);

трансгресива як результату каузації перетворення: ВТһЛаТИ, ВТЕЛЯТИ дієсл. недок. 1. (набувати матеріальних тілесних форм) втіляти: Бесъ приоболокс\# 3 неи в тһло (Київ, 1625 Сур.Сл. 126 зв.) [CУМ XVI-XVII ст., випуск 5, с. 70-71]; ДОМАЯТИСЯ. 1. Прилагая чрезмерные усилия, достигнуть какого-л. результата. А видите вы и сами, каково от царя литовскому послу бережение, чего онъ домаялся. Крым. д. II, 379. 1517 г. 2. Перенося лишения, дожить до какого-л. момента. Какъ до воды домаялись, весною на плотахъ поплыли. Ав. Ж., 181. 1673 г. [Тимченко, К. 2, с. 35]; УМАТНЯТИ, дієсл. Завлекать, обольщать. Свһтлыми надһями иныхъ уматняючи. АП. 1700 [Тимченко, К. 2, с. 427]; В3ГРБВАТИ дієсл. недок. Нагрівати, зігрівати, гріти: то єсть хлђбъ котора далъ вамъ ку ядєнью.. и всєгды збира́ли з пора́нки. а коли слицє взгрђва́ло, тє́ды сє ростоплА́ло (серед. XVII ст. Хрон. 93 зв.) [СУМ, Вип. 4, с. 19]; ЖИРОВАТИ дієс. Харчуватися. къ кон поки в лhсh $3^{\mathrm{s}}$ дикими бестіами жирUэтъ, в $^{\mathrm{s}}$ людской владзы не бываетъ (Мак., 215) [Тимченко, К. 1, с. 37]; УМЕРТВЯТИ, гл. Умерщвлять. Умертвити тhло свое. Гал. 147. [Тимченко, К. 2, с. 427];

темпоратива - часового показника: СНhДАТИ, гл. Завтракать. Онъ в дому моемъ.. 30 мною снһдалъ. Кн. Луцк. 1565, л. 278 [Матеріали до словника писемн. та книж. укр. мови XV-XVIII ст., кн. 2, с. 338]; ОТВЕЧЕРАТИ, гл. Отужинать. Отвечеравши повернулемся въ городъ на ночь. Дн. Марк. II. 147 [Тимченко, К. 2, с. 60]; ВЕЧЕРЯТИ, ВЕЧЕРАТИ, ВЕЧЕРАТЬ, ВЕЧЕРАТИ дієсл. недок. Вечеряти: нє годно тобъ со мною вєчєрАти (1489 Чет. 310) [СУМ, Вип. 4, с. 9]. Відіменникові деривати у староукраїнській літературній мові охарактеризовано за структурними і мотиваційними процесами, а тип мотивації, іiі різновид та компонент, вербалізований в ономасіологічній ознаці відіменникових дієслів, визначає семантичну групу предикатів, позначених дієслівними одиницями. Мотиваційні процеси староукраїнських відіменникових дієслів простежуються як у пропозиційно-диктумній, так і в асоціативно-термінальній мотивація ${ }^{25}$. Пропозиційно-диктумна мотивація староукраїнських відіменникових дієслів є найбільш поширеною у дієслівній системі XIV-XVII ст., мотиватори дієслів вибираються зі сфери предикатно-

25 Лукин М.Ф. Переход слов из одной части речи в другую и их трансформационные причинно-следственные связи в современном русском литературном языке. Проблемы словообразования русского и украинского языков. Киев-Донецк : Вища школа, 1976. С. 5-33. 
аргументної структури концепту і мають прямі значення. Асоціативнотермінальна мотивація відіменникових дериватів у дієслівній системі староукраїнської літературної мови простежується на виборі мотиватора з компонента неістинних, метафоричних знань ${ }^{26}$.

Дієслова із суфіксом -rb- $(>-i-)$. Дієслова з суфіксом - $\mathrm{b}-(>-\mathrm{i}-)$ у процесі творення слова разом 3 передсуфіксальною його частиною не тільки модифікують лексичне значення передсуфіксальної частини слова, але одночасно граматично оформлюють нейтральну передсуфіксальну частину, а тим самим і все слово. «Слово, - говорить О. Потебня, - містить у собі вказівку на певний зміст, властивий тільки йому одному, а разом 3 тим вказівку на один або кілька спільних розрядів, що звуться граматичними категоріями, під які зміст цього слова підводиться нарівні зі змістом багатьох інших» ${ }^{27}$. Залежно від семантики твірного слова похідна одиниця може виконувати функцію трансгресива як результату каузації перетворення: ПОКОЗА×hnnbnbNNNTИ, дієсл. Сделаться казаками. Инніе сами боячися пановъ своихъ и жолнһрства, же будучи мужиками покозачились, за Хмелницкимъ на Украину уступовали. Гр. 102. Жителһ тамошніе также покозачһли. Вел. IV.76 [Матеріали до словника писемн. та книж. укр. мови XV-XVIII ст., кн. 2, c. 153]; ОДhТИНһТИ, гл. Впасть в детство. Нынһ одһтинһль еси. АЮЗР. ІІ, 220 (И. Выш.) [Матеріали до словника писемн. та книж. укр. мови XV-XVIII ст., кн. 2, ст. 35]; ПОБһСНhТИ, гл. Сделаться подобным бесу, взбеситься. Не толко подһтинһли, але смиле мовлю, што и побһснили. АЮЗР. II, 220 (И. Выш.) [Матеріали до словника писемн. та книж. укр. мови XV-XVIII ст., кн. 2, ст. 116]; ПОПОПЕЛһТИ, гл. Обратиться в пепел. Широкого авнства мазанки попопельти. АП. 1802; БУТНhТИ дієсл. недок. Трухлявіти, трухнути: во наше(м) сӥто(м) законһ не находитс\# и(ж) бы сӥтыи рһчи имһли гнити или битнһти (к. XVI ст. - поч. XVII ст. Кн. о лат. 128 зв.) [CУМ XVI-XVII ст., випуск 3, ст. 104]; ОТРУПһТИ, гл. Сделаться трупом. Отрупиль, бездушенъ сталь. АЮЗР. II, 207 (И. Выш) [Матеріали до словника писемн. та книж. укр. мови XV-XVIII ст., кн. 2, ст. 70]; ПОШКОРУПһТИ, гл. Покрыться корой, обледенеть (о снеге). Снһгъ пошкорупиль. Дн. Марк. III, 249 [Матеріали до словника писемн. та книж. укр. мови XV-XVIII ст., кн. 2, c. 204]; ЗА×ЕРВОНһТИ, гл. Покраснеть. Тһло Христово зачервонило. Гал. 1, 111 [Матеріали до словника писемн. та книж. укр. мови XV-XVIII ст., кн. 1, с. 297]; ПОЕРЕТИ×һТИ, гл. Сделаться еретиками. Bch поеретичhли. АЮЗР. II, 209 (И. Выш) [Матеріали до словника писемн. та

26 Роль человеческого фактора в языке: Язык и картина мира / Отв. ред. Б.А. Серебренников. Москва : Наука, 1988. 216 с.

${ }^{27}$ Потебня А. Мысль и язык. А. Потебня. Изд., 5, 1926. 214 с. 
книж. укр. мови XV-XVIII ст., кн. 2, ст. 144]; ПОШЛЯХТhТИ, гл. Одворяниться. Пошляхтили и погорили есте. АЮЗР. II, 223 (И. Выш) [Матеріали до словника писемн. та книж. укр. мови XV-XVIII ст., кн. 2, с. 204]; ОБЛЕДЕНһТИ. Обледенеть, покрыться льдом. Пришли... мы пһши на Волуйку, для того снһги были большия и морозы лютые, и снһхъ обледенһль, лошедьми было һхать... нельзе. Дон. д. V. 556. 1660 г. ОБЛhДhТИ. Побледнеть, стать бледным. И видһ я паки въ вретищихъ и в попелһ ходяща, въ алчьбһ и в жажи и в пощеньи обледһвша. Пролог (БАН $\left.{ }^{2}\right) .140$ об. XIV в.; ОЧЕРНhТИ, гл. Почернеть. Надулся якъ мhхь $u$ углеви подобенъ очернһль. Пал. 474 [Тимченко, К. 2, с. 77].

Староукраїнські відіменникові деномінативи репрезентовані широким спектром значень мотивуючих іменників, виражених експерієнтивом - носієм психічної діяльності: ВЗБһСһТИ. Взбеситься, впасть в исступление. И льють [пьяницы вино] яко въ утлу съсудину, дондһже възбһсһють отъ пьянства. Пон. III, 101. XIV в. - Ср. взбһснһти [Матеріали до словника писемн. та книж. укр. мови XV-XVIII ст., кн. 1, ст. 37]; ВЗБЪСНЪТИ дієсл. док. Те саме, що взбъситисл: Если... всь в згодъ и едности въры будучи, а един всбъснђвши и зеретичившйся оторгнувся от лика или почту върных..., то бы и тая хула пала на апостолы (1608-1609 Виш. Зач. 214) [СУМ, Вип. 4, с. 15].

Темпоратива - часового показника: ДНһТИ, гл. Рассветать. Почало днhти. Рук. хр. 233 [Матеріали до словника писемн. та книж. укр. мови XV-XVIII ст., кн.1, с. 210]; РОЗОДНһТИСЯ, гл. безл. Рассвесть, наступить дню. Гды розоднһлося, прибравшися жидове поткалися зъ Антоніемъ мужне. Рук. хр. 203 [Матеріали до словника писемн. та книж. укр. мови XV-XVIII ст., кн. 2, с. 284]; О3hМhТИ, гл. Поселиться на зиму; расположиться на зимние квартиры. Шведскій Король... озһмивши въ Гольштейнһ не тратиль даромъ часу. Вел. I, 344 [Матеріали до словника писемн. та книж. укр. мови XV-XVIII ст., кн. 2, с. 37]; ВЕЧЕРБТИ дієсл. недок. Вечоріти: vesperare, вєчєрђти (1642 ЛС 411); inuesperasco, вєчєрью (Там же, 245) [СУМ, Вип. 4, с. 8]. Наведені вище відіменникові дієслівні одиниці староукраїнської літературної мови характеризують часові обмеження окресленої ситуації, тому мотиваційна функція випродуковується в дієсловах, пов'язаних із діяльністю, яка стосується часових проміжків.

Партоніма як частини цілого: ОКРИЛАТһТИ, гл. Окрылеть. А такъ окрилатһвши, самій южъ безпечне Долһтhвъ до неба, живши до конца статечне. Вел. III, 10 [Матеріали до словника писемн. та книж. укр. мови XV-XVIII ст., кн. 2, с. 39]; ОБЕЗГЛАСһТИ дієсл. Лишиться голоса, охрипнуть. Да которой чльвкъ обезгласеетъ, ино тое травы зори корень ясти на дьще сердще, ино вельми гортань чистить. Росп. травам, 221 об XVII в.; ОБЕЗЗАПАСһТИ. Лишиться запасов 
продовольствия. Будучи мы [дети боярские] на твоей гомударевһ службһ обһдняли и клячами отпали, а сами обеззапасһли и помираемъ голодною смертью АМГ II. 545. 1656 г.; ОПОВИДһТИ, гл. (пл. opowiedzieć). Возвестить. Пришли, приходять и выполняются, любомудрый чителнику, оные дни и лита, о которыхъ Господь Богъ нашъ Іисусь Хр. оповидһль, мовячи. Пал. 314 [Тимченко, К. 2, с. 47]. Відіменникові дієслова, охарактеризовані партонімом як частини цілого, мотивовані диктумом компонента ситуації, i за загальним механізмом структурно-мотиваційного словотворчого процесу цей тип мотивації є метонімічним.

У староукраїнській мові XIV-XVII ст. у дієслівній системі словотворення простежується гештальтно-метафоричний різновид асоціативно-термінальної мотивації - використовує мотиватор-асоціат, що виник на підставі аналогізації зорових, слухових, смакових відчуттів, які формують цілісні нерозчленовані структури свідомості гештальти: голубһти дієсл. недок. (мати голубий колір) голубіти: голUбһю columbesco (Уж. 1645, 60 зв.) [СУЛМ XVI-XVII ст., випуск 7, с.11]; ОСОЛһТИ, гл. Посолить. Если бы соль смакъ оутратила, то чим бы осолено было. Пер. ев. 38 [Тимченко, К. 2, с. 55]; ОСОЛОДһТИ, гл. Усладиться. Яко медь осолодһеть памятка его. Пал. 1135 [Тимченко, К. 2, с. 55]; ВЗЛЂТВТИ дієсл. док. (піднятися вгору) злетіти: Ста́ло са́ тє́ды въ вє́чоръ, и взлЂтъвши пєрєпю́рки Фкри́ли обо́зъ (серед. XVII ст. Хрон. 91 зв.) [СУМ, Вип. 4, с. 23]; МРһТИ, гл. Моросить. Черезъ ночъ мрһль дожчъ маленькій. Дн. Марк. II, 332 [Тимченко, кн. 1, ст. 437]; ОДЕБЕЛhТИ, гл. Огрубеть. Одебелили и окаменһли сердиемъ. АЮЗР. ІІ, 227 (И. Выш.) [Тимченко, кн. 2, с. 31]; ЗЕЛЕНЪТИ. Зеленеть. Откуду зеленъеть змарагдово есство на всякое время, а не на веснђ тъкмо. Шестодвев Г. Пизида, 44. $\mathrm{XV}$ в. [Тимченко, кн. 1, с. 3]. Староукраїнські відіменникові деривати гештальтно-метафоричного різновиду асоціативно-термінальної мотивації вибирають мотиватор, що $\epsilon$ знаком іншого концепту, і утворює зв'язок 3 позначуваним на основі аналогізації, що трансформується в гештальт на основі загального метафоричного механізму дериваційного процесу.

\section{ВИСНОВКИ}

Історія дериваційних процесів мови української народності, зафіксованої у писемних пам'ятках староукраїнського періоду XIV-XVII ст., презентує етапи становлення дієслівної словотворчої системи та вочевиднює імплементацію тих змін, що формують граматичну будову мови на певному історичному етапі. Якщо розвиток мови $\epsilon$ поступовим вдосконалюванням іiі граматичної будови, то в галузі словотворчої 
системи мови це вдосконалювання виражалося у тенденції до скорочення низки синонімічних суфіксів, до усунення суфіксальної і префіксальної різноманітності, до зменшення кількості афіксів, здатних входити у зв'язок з тією чи тією основою, до закріплення означених афіксів за означеними основами, що проілюстровано у писемних пам'ятках староукраїнської літературної мови XIV-XVII ст. Чисельною групою у староукраїнській літературній мові XIV- XVII ст. були дієслівні утворення від іменних основ (відіменникового та відприкметникового походження). Ці похідні утворення розрізняють дві категорії: 1) дієслова, що деетимологізувалися i перестали усвідомлюватися як похідні, внаслідок занепаду основного слова або зруйнування смислового зв'язку 3 ним; 2) дієслова, у яких чітко простежується мотиваційний зв'язок 3 основним словом.

До першої категорії відносимо деномінативи здебільшого безпрефіксні, утворені як від іменникових, так і від прикметникових твірних основ. Такі дієслівні одиниці вказують на перехід у відповідний стан та перебування в ньому. Відіменні дієслова, зафіксовані у писемних пам'ятках XIV-XVIII ст., мали найчисельнішу групу із суфіксом -и-, що відзначався високою продуктивністю та широкою вживаністю: боронити, пустошити, бъдити, владити, робити, питати, рубити, дурити, мътити, значити, мьстити, мочити, обидити, пакостити, хибити, тямити, бђдовати, вђстити, владати. Семантичний зв’язок між мотивуючими іменниками та похідними дієслівними одиницями історично послабився. Прикметно, що розглянуті деривати функціонують у сучасній українській літературній мові.

До другої категорії належать номінативи i суфіксальні, іпрефіксальні, утворені шляхом словотвірних та мотиваційних процесів граматикалізації мотивуючої бази іменних частин мови під граматичну категорію дієслівної основи: БУБЕНЬ $\rightarrow$ БУБНИТИ, БИЧКАРЬ (пастух) $\rightarrow$ БИЧОВАТИ, ДЬЯКОНОВАТИ, поваровати, ПОРАНОВАТИСЯ, ОБКУЩЕВАТИ, посольствоваТИ, ВРАЧЕВАТИ, 3ВБРИТИСЯ, заядовитися, СНhДАТИ, поКОЗА×hnnbnbNNNTИ, згноити, замусорити, КНУТОВАТИ, ВЕЧЕРАТИ, КОРОНОВАТИ, ПЕРЕЛһТОВАТИ тощо. Відіменникові дієслівні деривати староукраїнської літературної мови пропозиційно-диктумної мотивації охарактеризовано за різновидами на підставі вибору мотиватора з таких аргументів диктуму: агенса-діяча, релятива, експерієнтива, інструментива, медіатива, трансгресива, локатива, темпоратива, фінітива, партоніма. Пропозиційно-диктумна мотивація характеризується вибором мотиваційної бази дієслова з компонентів істинних, об'єктивних знань про позначуване, вербалізованих граматично i мотиваційно у знаках $з$ прямим значенням. Історично 
словотворча система мови і структурно і мотиваційно розвивається нерівномірно, і мова на кожному етапі свого розвитку характеризується різним ступенем еволюції розвитку граматичної будови, зокрема і дериваційних процесів.

Вочевиднено, що дієслова відіменникового походження утворювались в основному від мотивуючих іменників чоловічого роду на приголосний за допомогою дієслівних суфіксів -и-..., -а-(^), -b-(>-i), були найпродуктивнішими словотвірними формантами у дієслівній системі староукраїнської літературної мови. Дієслівні одиниці із зазначеними вище словотвірними формантами широко вживані у сучасній українській літературній мові.

Протягом історичного розвитку мотивуючий зв'язок між іменником i дієсловом може зникати або послаблюватися. Безсумнівно, деякі дієслівні деривати, які у староукраїнській літературній мові мали одне семантичне значення, а в сучасній українській літературній мові інше: ОБКУЩЕВАТИ, гл. (сделать привал, расположиться); КОБЗУВАТИ, дієсл. (гнушаться, брезговать); голчити дієсл. (гомонеть, кричать, шуметь); ДОЖДИТИ дієсл. недок. (цсл. дъждити) 2. Переносне значення. (густо, рясно спати); ВИХРИТИ, гл. (мутить, возбуждать раздор, смуту); ШКАРОДА, с.ж. (гнусность, мерз ость) ШКАРАДИТИ, дієсл. (пл. szkaradzic). (пачкать; осквернять); БЛЮДОЛИЗЬ, м. (тот, кто любит поживиться за чужой счет) $\rightarrow$ БЛЮДОЛИЗИТИ (искать чужих обедов, объедаться за чужой счет). Такі дієслівні деривати відносять до немотивованих або до псевдомотивованих, що відрізняються наявністю формального, умовного мотиватора у другому випадку. Зазвичай псевдомотивація пояснюється етимологічними, діахронними процесами у словотвірній системі та у семантичній і морфемній структурі слів. Такі деномінативи належать до похідних, але немотивованих слів, оскільки формально ономасіологічна ознака в них виокремлюється, а ономасіологічний базис бере на себе головну мотиваційну функцію, і такий словотвірний процес ми позначаємо як формальну граматикалізовану мотивацію.

Отже, дієслівна система староукраїнської мови XIV-XVII ст. дає змогу констатувати, що дієслівні номінативи, утворені від іменників за допомогою дієслівних суфіксів -и-.., -а-(^), -ь- (> -i-), випродуковують різні способи творення слів, різні словотворчі ресурси, вочевиднюють широкий структурно-мотиваційний масив похідних дієслівних одиниць, що активно функціонували у староукраїнському періоді i, безсумнівно, кваліфікують словотвірну систему сучасної української літературної мови. Перспективу подальших студій убачаємо передовсім у всебічному дослідженні дериваційної системи українського дієслова в плані когнітивно-ономасіологічного виявлення. 


\section{АНОТАЦІЯ}

У статті охарактеризовано староукраїнські відіменникові деривати за структурними і мотиваційними процесами, а тип мотивації, iї різновид та компонент, вербалізований в ономасіологічній ознаці відіменникових дієслів, визначає семантичну групу предикатів, позначених дієслівними одиницями. Мотиваційні процеси староукраїнських відіменникових дієслів простежуються як у пропозиційно-диктумній, так і в асоціативнотермінальній мотиваціях. Пропозиційно-диктумна мотивація староукраїнських відіменникових дієслів $\epsilon$ найбільш поширеною у дієслівній системі XIV-XVII ст., мотиватори дієслів вибираються зі сфери предикатно-аргументної структури концепту і мають прямі значення. Асоціативно-термінальна мотивація відіменникових дериватів у дієслівній системі староукраїнської літературної мови простежується на виборі мотиватора з компонента неістинних, метафоричних знань. У дієслівному словотворі староукраїнської літературної мови виокремлюються модусно мотивовані відіменні деривати, що характеризуються використанням оцінного сприймання мотиваторів мовцями.

\section{ЛІТЕРАТУРА}

1. Бабушкин А.П. Типы концептов в лексико-фразеологической семантике языка. Воронеж : Изд-во Воронеж. ун-та, 1996. 104 с.

2. Бевзенко С.П. Із історії словотвору дієслів української мови. Наук. збірн. Ужгородського ун-ту, 1958. Вип. 35. С. 3-20.

3. Бойчук В.М. Типологія внутрішньої форми слова у десубстантивному словотворі : автореф. дис. ... канд. філол. наук : 10.02.01. Івано-Франківськ, 1997. 18 с.

4. Бондарко А.В. Функциональная грамматика / Отв. ред. В.Н. Ярцева. Ленинград : Наука, 1984. 133 с.

5. Виноградов В.В. Понятие внутренних законов развития языка. Вопросы языкознания. № 2. 1952. С. 33.

6. Гумецька Л.Л. Нарис словотворчої системи української актової мови XIV-XV ст. Вид-во Академії Наук Української РСР. Київ, 1958. $297 \mathrm{c}$.

7. Кияк Т.Р. Мотивированность лексических единиц. Львів : Вища школа, 1988. $161 \mathrm{c}$.

8. Клименко Н.Ф. Словотворча структура і семантика складних слів у сучасній українській мові. Київ : Наукова думка, 1984. 251 с.

9. Кочерга Г.В. Мотивація відіменникових дієслів у сучасній українській мові. Вісник Черкаського ун-ту. Сер.: Філол. науки. Черкаси, 2001. Вип. 25. С. 103-108. 
10. Кочерга Г.В. Мотивація відіменникових дієслів у сучасній українській мові (когнітивно-ономасіологічний аспект) : дис. ... канд. філол. наук. Одеса, 2003. 200 с.

11. Кубрякова Е.С. Теория мотивации и определение степеней мотивированности производного слова. Актуальные проблемы русского словообразования. Ташкент : Изд-во Ташкентского ун-та, 1976. C. 285-292.

12. Лукин М.Ф. Переход слов из одной части речи в другую и их трансформационные причинно-следственные связи в современном русском литературном языке. Проблемы словообразования русского и украинского языков. Киев-Донецк : Вища школа, 1976. С. 5-33.

13. Погиба Л.Г. Семантичне поле відіменникових дієслів спільної дії в сучасній українській мові. Питання граматичної будови української мови : збірн. наук. праць. Київ : Вид-во КДПІ, 1979. С. 75-87.

14. Потебня А. Мысль и язык. А. Потебня. Изд., 5, 1926. 214 с.

15. Потебня А.А. Из записок по русской грамматике. Т. II. Харьков, 1888. C. 25.

16. Півторак Г.П. Історико-лінгвістична славістика. Вибрані праці. Київ : НВП «Вид-во «Наукова думка» НАН України», 2015. 512 с.

17. Роль человеческого фактора в языке: Язык и картина мира / Отв. ред. Б.А. Серебренников. Москва : Наука, 1988. 216 с.

18. Селиванова Е.А. Когнитивная ономасіологія : монографія. Київ : Фітосоціоцентр, 2000. 248 с.

19. Селіванова О.О. Когнітивний аспект дослідження явища мотивації. Лінгвістичні студії. Черкаси : Брама: ІСУЕП, 1999. Вип. 3. C. 21-27.

20. Селіванова О.О. Складне слово: мовні моделі світу. Черкаси : ЦНТІ, 1996. 297 c.

21. Ченки А. Семантика в когнитивной лингвистике. Фундаментальные направления в современной американской лингвистике. Москва : Изд-во Моск. ун-та, 1997. С. 340-369.

22. Ширшов И.А. Множественная словообразовательная мотивация в современном русском языке. Ростов-на-Дону : Изд-во Кубанского ун-та, 1981. $117 \mathrm{c}$.

23. Штанденко У.М. Відіменний суфіксальний словотвір дієслів у староукраїнській мові XIV-XVIII ст. Київ : Інститут української мови НАН України, 2008. 208 с.

24. Языковая номинация. Общие вопросы / Отв. ред. Б.А. Серебренников. Москва : Наука, 1977. 354 с.

25. Янценецкая М.Н. Мотивационные отношения в лексике и лексическое гнездо. Семантическая структура слова. Кемерово : Изд-во Кемеровского ун-та, 1984. С. 3-17. 
26. Янценецкая М.Н. Семантические вопросы теории словообразования. Томск : Изд-во Алтайского ун-та, 1979. 237 с.

27. Словник української мови XVI - першої половини XVII ст. : у 28 вип. / Відп. ред. Д. Гринчишин та ін. НАН України Інститут українознавства ім. І. Крип’якевича. Львів, $1994-2005$. Вип. 1-12.

28. Матеріали до Словника писемної та книжної української мови XV XVIII ст.: у 2 кн. / Є. Тимченко. Упор. В.В. Німчук, Г.І. Лиса. НАН України, Українська Вільна Академія Наук у США. Київ-Нью-Йорк, 2002-2003. (Пам’ятки української мови. Серія словників). Кн. 1-2.

Information about the authors: Kocherha H. V.,

Candidate of Philological Sciences, Associate Professor, Associate Professor at the Department of Ukrainian Linguistics and Applied Linguistics Bohdan Khmelnytsky National University of Cherkasy 81, Shevchenko blvd, Cherkasy, 18005, Ukraine

Martynovska Yu. O.,

Master's Student

Institute of the Ukrainian Philology and Social Communications of Bohdan Khmelnytsky National University of Cherkasy 81, Shevchenko blvd, Cherkasy, 18005, Ukraine 